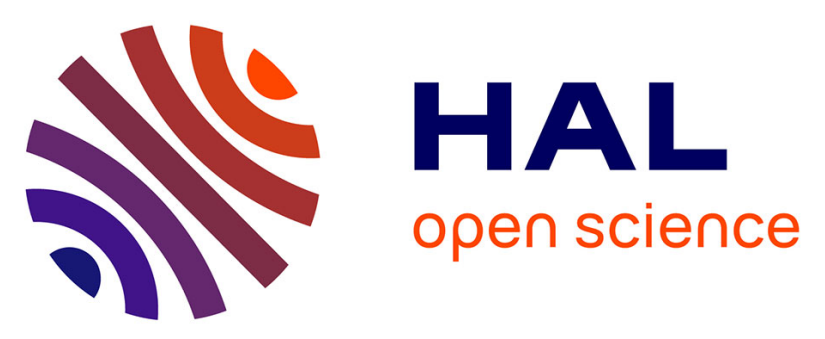

\title{
Biochemical evidences for M1-, M17- and M18-like aminopeptidases in marine invertebrates from Cuban coastline
}

Isel Pascual Alonso, Laura Rivera Méndez, Mario E Valdés-Tresanco, Lotfi Bounaadja, Marjorie Schmitt, Yarini Arrebola Sánchez, Luis Alvarez Lajonchere, Jean-Louis Charli, Isabelle Florent

\section{To cite this version:}

Isel Pascual Alonso, Laura Rivera Méndez, Mario E Valdés-Tresanco, Lotfi Bounaadja, Marjorie Schmitt, et al.. Biochemical evidences for M1-, M17- and M18-like aminopeptidases in marine invertebrates from Cuban coastline. Zeitschrift fur Naturforschung C, 2020, 10.1515/znc-2019-0169 . hal-02902526

\section{HAL Id: hal-02902526 \\ https://hal.science/hal-02902526}

Submitted on 24 Jul 2020

HAL is a multi-disciplinary open access archive for the deposit and dissemination of scientific research documents, whether they are published or not. The documents may come from teaching and research institutions in France or abroad, or from public or private research centers.
L'archive ouverte pluridisciplinaire HAL, est destinée au dépôt et à la diffusion de documents scientifiques de niveau recherche, publiés ou non, émanant des établissements d'enseignement et de recherche français ou étrangers, des laboratoires publics ou privés. 


\section{Biochemical evidences for M1-, M17- and M18-like aminopeptidases in marine invertebrates from Cuban coastline}

Isel Pascual Alonso ${ }^{1 *}$, Laura Rivera ${ }^{1}$, Mario E. Valdés-Tresanco ${ }^{1,2}$, Lotfi Bounaadja ${ }^{3}$, Marjorie Schmitt ${ }^{4}$, Yarini Arrebola ${ }^{1}$, Luis Alvarez Lajonchere ${ }^{5}$, Jean-Louis Charli ${ }^{6}$ and Isabelle Florent ${ }^{3}$

${ }^{1}$ Center for Protein Studies, Faculty of Biology, University of Havana, Havana, Cuba; ${ }^{2}$ Department of Biological Sciences, University of Calgary, Calgary, Canada; ${ }^{3}$ Molécules de Communication et Adaptation des Microorganismes (MCAM, UMR 7245), Muséum National d'Histoire Naturelle, CNRS, Paris, France; ${ }^{4}$ Laboratoire d'Innovation Moléculaire et Applications - Université de Haute-Alsace, Université de Strasbourg, CNRS, LIMA UMR7042, Mulhouse, France; ${ }^{5}$ Museum of Natural History "Felipe Poey"; Faculty of Biology, University of Havana, Cuba; ${ }^{6}$ Instituto de Biotecnología, Universidad Nacional Autónoma de México (UNAM), Cuernavaca, México.

*Corresponding author: Isel Pascual, PhD. Center for Protein Studies, Faculty of Biology, University of Havana, 25 \# 455, between J and I, Plaza de la Revolución, Havana, Cuba, CP 10 400. Email: isel@fbio.uh.cu, Tel. +53 (7) 8324830, Fax: +53 (7) 8321321 


\begin{abstract}
Metallo-aminopeptidases (mAPs) control many physiological processes. They are classified in different families according to structural similarities. Neutral mAPs catalyze the cleavage of neutral amino acids from the N-terminus of proteins or peptide substrates; they need one or two metallic cofactors in their active site. Information about marine invertebrate's neutral mAPs properties is scarce; available data are mainly derived from genomics and cDNA studies. The goal of this work was to characterize the biochemical properties of the neutral APs activities in eight Cuban marine invertebrate species from the Phyla Mollusca, Porifera, Echinodermata, and Cnidaria. Determination of substrate specificity, optimal $\mathrm{pH}$ and effects of inhibitors and ions (1,10-phenanthroline, cobalt, amastatin and bestatin) on activity led to the identification of distinct neutral AP-like activities, whose biochemical behaviors were similar to those of the M1 and M17 families of mAPs. Additionally, M18-like glutamyl AP activities were detected. Thus, marine invertebrates express biochemical activities likely belonging to various families of metallo-aminopeptidases.
\end{abstract}

\title{
Keywords
}

Metallo-aminopeptidase; marine invertebrate; M1 family; M17 family; M18 family 


\section{Introduction}

Proteases are involved in almost all physiological processes [1,2]. Their importance is underscored by overlapping and redundant activities, and functional conservation throughout the eukaryotic lineage [3]. Proteases have adapted to the wide range of biochemical conditions found in complex organisms displaying different catalytic mechanisms for substrate hydrolysis. They are classified according to their hydrolytic mechanism, one of them being the metallo type [1]. Metalloaminopeptidases catalyze the cleavage of neutral amino acids from the N-terminus of substrates; they need one or two metallic cofactors in their active site, often zinc. Depending on enzyme structure, they have been classified in several metallo-peptidase families such as M1, M17 and M18 $[1,3,4]$. Excluding viruses, most of these families are present in all living organisms $[1,3,4]$.

Neutral metallo-aminopeptidase (APN, EC 3.4.11.2) is a M1 family member [3]. APN catalyzes the cleavage of neutral and basic amino acids from the $\mathrm{N}$-terminus of substrates, leading to their activation/inactivation in the extracellular space. In mammals, APN is a type II membrane protein generally found as a homodimer [5,6]. Mammalian APN has an ectodomain containing the zincbinding active site sequence $\underline{\mathrm{HEXX}} \underline{\mathrm{H} X 18} \underline{\mathrm{E}}$ (underlined amino acids being zinc-ligands) and the exopeptidase signature GXMEN [5,6]; it processes peptides like enkephalins, peptides of the renin angiotensin system and chemokines, and is involved in cell adhesion, endocytosis, and as a receptor for coronavirus [7]. Mammalian leucyl aminopeptidase (LAP, EC 3.4.11.21, M17 family) is cytosolic and breaks down peptide products of intracellular proteinases [4]; its two metal ions are 'co-catalytic'; both are zinc in mammals [4]. M18 enzymes in mammals are preferentially expressed, with high enzymatic activity, in neurons and neuroendocrine tissues, but they also regulate the renin-angiotensin system and blood pressure [8,9]. Metallo aminopeptidases from M1, M17 and M18 families are also critical in single cell eukaryotes; for example, in Apicomplexan protist parasites like Plasmodium falciparum they are involved in the final steps of hemoglobin digestion $[10,11,12]$. 
Marine invertebrates are an important source of bioactive molecules such as peptidases [13] of different mechanistic classes. These biomolecules are involved in nutrition, reproduction, and communication. However, knowledge about marine invertebrate metallo-aminopeptidase activities $[14,15]$ and inhibitors $[16,17]$ is scarce; data regarding the presence of metallo-aminopeptidases come mainly from genomic and cDNA studies [18-21].

Recently, we identified neutral aminopeptidase-like activities in crude extracts from eight Cuban invertebrate species from the Phyla Mollusca, Porifera, Echinodermata, and Cnidaria [22]. Based on the antecedents, and the relevance for phylogenetic studies of the identification of M1, M17 and M18 activities in marine invertebrates, the main goal of the current study was to characterize the functional biochemical properties (using kinetic approaches) of the neutral and glutamyl aminopeptidase-like activities detected in these species.

\section{Materials and methods}

\subsection{Materials and animals}

L-Leu-AMC, L-Ala-AMC, L-Phe-AMC, L-Tyr-AMC, L-Arg-AMC, L-Asn-AMC, L-Ser-AMC, LAsp-AMC, L-Glu-AMC, bestatin, amastatin, and 1,10-phenanthroline were purchased from SigmaAldricht. L-Leu-pNA and L-Glu-pNA were purchased from Bachem. Microsomes containing porcine kidney cortex glutamyl aminopeptidase (pAPA) and human placental APN (hAPN) were prepared as described [22], based on a previous report [23]. LAP (hLAP) was prepared from human placenta as described [22]. The recombinant form of PfA-M17 aminopeptidase (rPfA-M17) was produced as described [22]. Other reagents were of analytical grade. Marine invertebrates (Supplementary Material, Table 1) were identified by Luis Alvarez Lajonchere, a researcher of the Museum of Natural History "Felipe Poey” (Faculty of Biology, University of Havana, Cuba).

\subsection{Preparation of crude extracts from marine invertebrates}

Crude extracts from marine invertebrates were prepared as described [22]. Organisms were collected along the coast of Havana (Cuba), classified, transported alive on ice, and stored at -20 ${ }^{\circ} \mathrm{C}$ until aqueous extract preparation. Specimens for each species were thawed, washed with 
distilled water, dried on paper filter, weighted, cut into small pieces with sterile scissors and homogenized in distilled water $2: 1(\mathrm{~mL} / \mathrm{g})$ at $4{ }^{\circ} \mathrm{C}$ in a warring blender $(10 \mathrm{~s}$ for 3 repeated cycles). Homogenates were centrifuged at $10000 \mathrm{~g}$ for $30 \mathrm{~min}$ at $4{ }^{\circ} \mathrm{C}$. The supernatants were filtered on fiberglass to yield aqueous crude extracts. These extracts were extensively dialyzed versus $50 \mathrm{mM}$ Tris- $\mathrm{HCl} \mathrm{pH} 7.5$ (buffer A) using dialysis membranes with a 10000 Da cut off (Spectrapor) and kept at $-20^{\circ} \mathrm{C}$ until assayed for aminopeptidase activities.

\subsection{Protein concentration determination for marine extracts}

The protein concentration was determined at $280 \mathrm{~nm}$ as described by Scopes [24] using one unit as an arbitrary extinction coefficient $(0.1 \%, 1 \mathrm{~cm})$ and bovine serum albumin as standard in a GENESYS 10S UV-V spectrophotometer (Thermo Scientific).

\subsection{Monitoring of aminopeptidase enzymatic activities}

The activities of the neutral aminopeptidases used as controls (hAPN, rPfA-M17, hLAP) were measured using the substrate L-Leu-AMC in the specific conditions for each enzyme as described [22]. Briefly, in all cases kinetic assays were run at $37^{\circ} \mathrm{C}$ during 40 minutes in 96 well plates, and the linear region of the typical progress curve was used to calculate the initial rate. The AMC fluorescence was measured at $460 \mathrm{~nm}$ (bandwith: 40) upon excitation at $360 \mathrm{~nm}$ (bandwith: 40) in a BioTek FL600 fluoromark spectrofluorometer operating in the kinetic mode [22]. To avoid competition during inhibition assays, we used L-Leu-AMC at a concentration (10-500 $\mu \mathrm{M})$ equal or lower than one $\mathrm{K}_{\mathrm{M}}$ value [22]. Human placental aminopeptidase $\mathrm{N}$ activity $(0.25 \mathrm{mg} / \mathrm{mL})$ was measured using buffer A, with $0.030 \mathrm{mmol} / \mathrm{L}$ of L-Leu-AMC in a final assay volume of $200 \mu \mathrm{L}$. Human placental leucyl aminopeptidase activity $(0.84 \mathrm{mg} / \mathrm{mL})$ was measured using buffer A, with $0.200 \mathrm{mmol} / \mathrm{L}$ of L-Leu-AMC in a final assay volume of $200 \mu \mathrm{L}$. rPfA-M17 activity $(0.113$ $\mathrm{mg} / \mathrm{mL}$ ) was measured using buffer Tris HCL $50 \mathrm{mmol} / \mathrm{L} \mathrm{pH} 8,1 \mathrm{mmol} / \mathrm{L}$ Cobalt (Buffer B) with $0.050 \mathrm{mmol} / \mathrm{L}$ of L-Leu-AMC in a final assay volume of $100 \mu \mathrm{L}$. All enzymes were preincubated at $37{ }^{\circ} \mathrm{C}$ for $30 \mathrm{~min}$ before the addition of the substrate. One Unit of Enzyme Activity was defined 
as the amount of enzyme needed to produce $1 \mu \mathrm{mol}$ of AMC per min per $\mathrm{mL}$ of enzyme using a standard curve of AMC.

\subsection{Preliminary functional characterization of the invertebrate extract neutral} aminopeptidase-like activities

We previously reported that some marine invertebrate crude aqueous extracts increased the rate of substrate hydrolysis in aminopeptidase assays [22]. To confirm the presence of aminopeptidase-like activities, different amounts of the various crude extracts were assayed with L-Leu-AMC (0.025 $\mathrm{mM}$ ) in buffer A, in a final assay volume of $200 \mu \mathrm{L}$ [22]. The kinetic assays for the preliminary functional characterization described below were done as described above, and with a fixed amount of each crude extract inside the linear range of initial rate vs protein concentration: Nerita peloronta $(0.42 \mathrm{mg} / \mathrm{mL})$, Nerita versicolor $(0.29 \mathrm{mg} / \mathrm{mL})$, Lissodendoryx (Lissodendoryx) isodictyalis $(1.31 \mathrm{mg} / \mathrm{mL})$, Tripneustes ventricosus $(0.74 \mathrm{mg} / \mathrm{mL})$, Echinaster (Othilia) echinophorus $(0.07 \mathrm{mg} / \mathrm{mL})$, Stichodactyla helianthus $(0.42 \mathrm{mg} / \mathrm{mL})$, Bunodosoma granuliferum $(0.09 \mathrm{mg} / \mathrm{mL})$ and Physalia physalis $(5.47 \mathrm{mg} / \mathrm{mL})$.

\subsection{Effect of metallo-inhibitors on enzyme activity}

To test the effects of the metallo-peptidase inhibitor 1,10-phenanthroline $(1 \mathrm{mM})$, and of the metallo-aminopeptidase inhibitors amastatin $(100 \mu \mathrm{M})$ and bestatin (eight different concentrations in the range $0.05-50 \mu \mathrm{M}$ ), each aqueous crude extract and the control enzymes, were preincubated for $30 \mathrm{~min}$ at $37{ }^{\circ} \mathrm{C}$ with the inhibitor prior to the addition of L-Leu-AMC at $0.025 \mathrm{mM}$ as described above. The half maximal inhibitory concentrations $\left(\mathrm{IC}_{50}\right)$ for bestatin were determined by non-linear regression adjustment of the dose-response curves using the software GRAFIT 6.0 $(n=3)$.

\subsection{Effect of pH on enzyme activity}

The effect of $\mathrm{pH}$ on enzyme activity was determined using the following buffers, at $50 \mathrm{mM}$ : sodium acetate for $\mathrm{pH}$ 2.0-6.0; sodium phosphate for $\mathrm{pH}$ 6.0-7.5; Tris- $\mathrm{HCl}$ for $\mathrm{pH}$ 7.5-9.0; glycine for $\mathrm{pH} 9.0-12.0$. 


\subsection{Effect of substrates on initial rate, determination of $\mathrm{K}_{\mathrm{M}}$ for L-Leu-AMC and effect of}

cobalt on the activities vs L-Leu and L-Glu substrates

L-aa-AMC substrates (aa: Ala, Phe, Tyr, Arg, Asn, Ser, Asp and Glu) were tested at $100 \mu \mathrm{M}$ in buffer A. Extracts and control enzymes were preincubated for $30 \mathrm{~min}$ at $37{ }^{\circ} \mathrm{C}$ before substrate addition. For activity vs L-Glu-AMC, the effect of calcium at $1 \mathrm{mM}$ was assayed. Analysis of the results was based on initial rate for each substrate, setting the highest value to $100 \%$ and adjusting the other results accordingly. hAPN and rPfA-M17 were tested in parallel as control enzymes for M1 and M17 families, respectively, and data for PfA-M1 from [25] was also included in the analysis. To corroborate a Michaelis-Menten behavior (characteristic of an enzyme) for each crude extract, we determined the effect of the L-Leu-AMC concentration (seven different concentrations in the range 10-500 $\mu \mathrm{M}$ ) on initial rate of reaction and determined $\mathrm{K}_{\mathrm{M}}$ values. To identify potential M17 and M18 activities using a biochemical kinetic approach, we studied the effect of cobalt $\left(\mathrm{CoCl}_{2} 1 \mathrm{mM}\right)$ on the activity of crude extracts versus L-Leu-paranitroanilide (L-Leu-pNA; 300 $\mu \mathrm{M}$ ) and L-Glu-paranitroanilide (L-Glu-pNA; $300 \mu \mathrm{M}$ ), respectively. For L-Glu-pNA activities, the effect of bestatin $100 \mu \mathrm{M}$ (with or without $\mathrm{CoCl}_{2} 1 \mathrm{mM}$ ) was also assayed. In parallel, pAPA activity was assayed as a control for glutamyl aminopeptidase activity from the M1 family [1,3]. These assays were done in buffer A and in this case one Unit of Enzyme Activity was defined as the amount of enzyme needed to produce $1 \mu \mathrm{mol}$ of paranitroaniline per min per $\mathrm{mL}$ of enzyme. The results were expressed as percentage of Enzyme Activity vs control activity.

\subsection{Bioinformatic search for M1, M17 and M18 sequences in marine invertebrates}

A search for sequences belonging to the M1, M17 and M18 families in organisms closely related to those listed in Table 1 was performed in the UNIPROT database (www.uniprot.org). A multiple sequence alignment (MSA) was carried out using ClustalW [26]. The amino acid conservation of each position in the MSA was calculated using Consurf server [27].

\section{Results}

\subsection{Effect of metallo-inhibitors on enzyme activity}


During the screening of aqueous extracts of marine invertebrates from the Cuba coastline for the detection of inhibitory activities against neutral aminopeptidases we detected that some extracts increased L-Leu-AMC hydrolysis rate over the control values. These extracts were from: Nerita peloronta, Nerita versicolor, Lissodendoryx (Lissodendoryx) isodictyalis, Tripneustes ventricosus, Echinaster(Othilia) echinophorus, Stichodactyla helianthus, Bunodosoma granuliferum and Physalia physalis [22].

To initiate the biochemical characterization of these neutral aminopeptidase-like activities, we tested their susceptibility to metallo- and/or amino-peptidase inhibitors in assays using L-Leu-AMC as a substrate at $\mathrm{pH}$ 7.5. The neutral aminopeptidase activities were inhibited by more than 80 percent by $1 \mathrm{mM}$ of the metallo-peptidase inhibitor 1,10-phenanthroline. They were also reduced by the metallo-aminopeptidase inhibitor amastatin tested at $100 \mu \mathrm{M}$, with percentage of inhibition ranging from 30 to 75 depending on the species. The inhibitory effects of bestatin were dose dependent in all cases, with $\mathrm{IC}_{50}$ values in the range of $0.2-86 \mu \mathrm{M}\left(\mathrm{r}^{2}\right.$ values of the adjustment to the $\mathrm{IC}_{50}$ equation included in GRAFIT 6.0 software higher to 0.9971 in all cases) and concave behaviors indicating reversibility of the interaction (representative curves are shown in Fig. 1 A,B for the species Echinaster echinophorus and Stichodactyla helianthus; see also Supplementary Material, Fig. 1 for the rest of the species under study) (Table 1). Similar results were observed for the activities of the positive controls, hAPN, hLAP and rPfA-M17, assayed in parallel (Table 1; see Supplementary Material Fig. 1).

\subsection{Effect of pH on enzyme activity}

The effect of $\mathrm{pH}$ on the activities versus L-Leu-AMC depended on crude extract (Table 1); however, all extracts displayed a maximal activity in the 7-9 $\mathrm{pH}$ range, characteristic of neutral aminopeptidases from the M1 and M17 families. Furthermore, for five of the extracts, an additional peak of neutral aminopeptidase-like activity was also detected in the 4-5 $\mathrm{pH}$ range of values; this unexpected result indicates that these extracts contained at least two different molecular entities 
with neutral aminopeptidase activities, distinct in their optimal $\mathrm{pH}$. The optimal range of $\mathrm{pH}$ values for hAPN activity was 7.0-8.0 (Table 1).

\subsection{Effect of different substrates on the initial rate; determination of $K_{M}$ for L-Leu-AMC}

The hydrolysis rates at increasing substrate L-Leu-AMC concentrations displayed hyperbolic Michaelis-Menten behaviors $\left(\mathrm{r}^{2}\right.$ values of the adjustment to the Michaelis-Menten equation included in GRAFIT 6.0 software higher to 0.9712 in all cases); the $\mathrm{K}_{\mathrm{M}}$ values for L-Leu-AMC at pH 7.5 were determined for each extract and were in the 7-66 $\mu \mathrm{M}$ range (Table 1). These results corroborate the presence of neutral aminopeptidases in these extracts. Some of the hyperbolic curves are shown in Fig. 1 C,D for the species Echinaster echinophorus and Stichodactyla helianthus (see also Supplementary Material Fig. 2 for other species).

We also evaluated the initial hydrolysis rate of different L-aa-AMC substrates (aa: Leu, Ala, Phe, Tyr, Arg, Asn, Ser, Asp, Glu), tested at $100 \mu \mathrm{M}, \mathrm{pH} 7.5$ to preliminary study the specificity of each crude extract. Analysis of the results was based on initial rate for each substrate, setting the highest value to $100 \%$ and adjusting the other results accordingly (Fig. 2), as previously described [23]. Crude extracts from Nerita peloronta, Nerita versicolor and Stichodactyla helianthus had the highest initial rate of hydrolysis for L-Phe-AMC (Fig. 2 A,B,F); Stichodactyla helianthus extract also displayed a high hydrolysis rate for L-Tyr-AMC. The aqueous crude extracts from Echinaster (Othilia) echinophorus and Bunodosoma granuliferum had the highest initial rate of hydrolysis for L-Leu-AMC (Fig. 2 E,G), and that from Physalia physalis the highest initial rate of hydrolysis for L-Ala-AMC (Fig. $2 \mathrm{H}$ ). Interestingly, the crude extracts from Lissodendoryx (Lissodendoryx) isodictyalis and Tripneustes ventricosus showed the highest initial hydrolysis rate for L-Glu-AMC (without added calcium, Fig. 2 C,D); the hydrolysis rates were similar when $1 \mathrm{mM} \mathrm{CaCl} 2$ was added (not shown). All the aqueous crude extracts hydrolyzed L-Leu-AMC, L-Ala-AMC, L-PheAMC, L-Tyr-AMC and L-Arg-AMC with initial rates at least $20 \%$ of the highest rate (Fig. 2). The extracts also hydrolyzed L-Asn-AMC and L-Ser-AMC, but with lower initial rates than for other substrates, except for Lissodendoryx (Lissodendoryx) isodictyalis that showed significant hydrolysis 
of both substrates (Fig. 2 C). All crude extracts also hydrolyzed L-Glu-AMC with low initial rates, except those of Lissodendoryx (Lissodendoryx) isodictyalis and Tripneustes ventricosus, which showed the highest activities with this substrate. Extracts from Nerita versicolor, Nerita peloronta and Lissodendoryx (Lissodendoryx) isodictyalis produced a low initial rate of hydrolysis of L-AspAMC (Fig. 2 A,B,C). In parallel, we determined that for both hAPN and rPfA-M17 the highest activity was detected with L-Leu-AMC. hAPN activity with L-Ala-AMC was more than $80 \%$ that of the activity with L-Leu-AMC, and with L-Arg-AMC, L-Phe-AMC, and L-Tyr-AMC, 20-40\% of the activity with L-Leu-AMC. For rPfA-M17, we also detected some activity for L-Phe-AMC (31\% of the L-Leu-AMC activity) (Fig. 2). Data for PfA-M1 from [25] were also included for comparison (Fig. 2). Supplementary Material Table 2 shows substrate specificity for each extract and for hAPN, rPfA-M17 and PfA-M1 [25], according to decreasing order of initial rates.

Since cobalt increases M17 activities [28 stack], we tested the effect of $1 \mathrm{mM}$ of $\mathrm{CoCl}_{2}$ on the hydrolysis of L-Leu-pNA by the crude extracts at $\mathrm{pH}$ 7.5. Except for the Lissodendoryx (Lissodendoryx) isodictyalis extract, whose activity was barely changed by addition of $\mathrm{CoCl}_{2}$, for the other species, $\mathrm{CoCl}_{2}$ addition increased the activities by 16 to $48 \%$ (Table 2).

To determine whether the activities hydrolyzing L-Glu-pNA in crude extracts were M18- or M1like, we evaluated the effect of cobalt and the susceptibility to bestatin $100 \mu \mathrm{M}$ at $\mathrm{pH} 7.5$. In parallel, we assayed the effects of both on pAPA (as control of the M1 family) activity. In all the crude extracts, the addition of $1 \mathrm{mM} \mathrm{CoCl}_{2}$ increased the hydrolysis of L-Glu-pNA by $10 \%$ to $34 \%$ (Table 2). Additionally, the hydrolytic activities towards L-Glu-pNA at $\mathrm{pH} 7.5$ were not susceptible to bestatin $100 \mu \mathrm{M}$ (Table 2). On the contrary, $1 \mathrm{mM} \mathrm{CoCl}_{2}$ and $100 \mu \mathrm{M}$ bestatin decreased the activity of pAPA by $68 \%$ and $36 \%$ respectively (Table 2 ).

\subsection{Marine invertebrate M1, M17 and M18 sequences in data bases}

We detected 57 sequences highly related to M1 neutral aminopeptidase members in marine invertebrate species closely related (Phylum:Class) to those characterized in the present contribution. Most of the sequences are related to Mollusca:Gastropoda species; sequences from 
Echinodermata, Cnidaria:Anthozoa, Cnidaria:Hydrozoa and Porifera:Demospogiae were also identified. Most of these sequences have been described in genomic, transcriptomic and/or proteomic studies [20,21,29-31]. Studies specifically directed to M1 neutral aminopeptidases were done for Littorina species [19] and for Aplysia californica [18]. For the alignment shown in Fig. 3, we considered the conservation of the canonical sequences ${ }^{352} \mathrm{GxMEN}^{356}$ (red rectangle Fig. 3) and ${ }^{385} \mathrm{abxHEbbHbcx} 16 \mathrm{E}^{411}$ (numbers from human APN), where ' $\mathrm{x}$ ' is any amino acid, 'a' is most often valine or threonine, ' $b$ ' is an uncharged residue, and 'c' a hydrophobic residue. Conservation grade was calculated in the Consurf server [27], using as input the MSA of all sequences; it ranged from 3 (variable) to 9 (conserved) (Fig. 3, see Supplementary Material, Table 3).

On the other hand, we identified 18 sequences highly related with M17 leucyl aminopeptidase members in marine invertebrate species closely related (Phylum:Class) to those characterized in the present contribution. Sequences from Mollusca:Gastropoda, Echinodermata, Cnidaria:Anthozoa, Cnidaria:Hydrozoa and Porifera:Demospogiae were identified; they have been described in genomic, transcriptomic and/or proteomic studies [20,21,29-31]. For the alignment shown in Fig. 4A, we considered the conservation of amino acids involved in catalysis and metal coordination $\mathrm{K}^{282}, \mathrm{D}^{287}, \mathrm{~K}^{294}, \mathrm{D}^{305}, \mathrm{D}^{364}$ and $\mathrm{E}^{366}$, and of the canonical sequence ${ }^{362} \mathrm{NTDAEGR}^{368}$ (numbers from human LAP, red rectangle Fig. 4A). The conservation grade was 9 (conserved) for all the sequences, independently of the Phylum (Fig. 4A, see Supplementary Material, Table 4).

Finally, we found six sequences highly related with M18 aminopeptidase members in marine invertebrate species closely related (Phylum:Class) to those characterized in the present contribution. Sequences from Mollusca:Gastropoda, Cnidaria:Anthozoa, Cnidaria:Hydrozoa and Porifera:Demospongiae were identified, but none from Echinodermata; they have been described in genomic, transcriptomic and/or proteomic studies [20,21,30,31]. For the alignment represented in Fig. 4B, we considered the conservation of amino acids involved in catalysis and metal coordination $\mathrm{H}^{170}, \mathrm{D}^{260}, \mathrm{E}^{301}, \mathrm{E}^{302}, \mathrm{D}^{346}, \mathrm{H}^{349}, \mathrm{~K}^{374}, \mathrm{Y}^{381}, \mathrm{H}^{440}$ (numbers from human glutamyl aminopeptidase). 
The conservation grade was 9 (conserved) for all the sequences, independently of the Phylum (Fig. 4B, see Supplementary Material, Table 5).

\section{Discussion}

Marine invertebrate peptidases are involved in nutrition, reproduction, communication, and contribute to protection against predator, infection and competition [13-15]. In the present contribution we identified and characterized for the first time, using a biochemical kinetic approach, neutral aminopeptidase-like activities (that hydrolyze L-Leu-AMC at neutral $\mathrm{pH}$ ) in crude aqueous extracts from eight species of marine invertebrates from the Caribbean Sea: two mollusks, one sponge, two echinoderms and three cnidarians. These aminopeptidases have in common a great susceptibility to decreased $\mathrm{pH}$ and/or to the chaotropic agent TCA at $2.5 \%$, because their activities were lost after clarification [22] and minimal at $\mathrm{pH}$ values lower than 3 (not shown).

In all extracts, the activity vs L-Leu-AMC was highly susceptible to the general chelating agent metallo-inhibitor 1-10-phenantroline, indicating that the hydrolysis of the substrate is due to the presence of metallo-enzymes, as previously shown for Leu-aa hydrolyzing activities in marine invertebrates like Aplysia californica [15]. Additionally, hydrolysis was susceptible to the specific metallo-aminopeptidase inhibitors amastatin and bestatin, but bestatin $\mathrm{IC}_{50}$ values were extremely variable. Echinaster (Othilia) echinophorus showed the lowest $\mathrm{IC}_{50}$ value, in the submicromolar range, similar to Plasmodium falciparum M1 [25] and M17 aminopeptidases, which were used as positive control.

The neutral aminopeptidase activities found in Nerita peloronta, N. versicolor, Echinaster (Othilia) echinophorus, Stichodactyla helianthus and Bunodosoma granuliferum were characterized by similar optimal $\mathrm{pH}$ in the neutral range, and preference for neutral (including large hydrophobic side chains like Phe and Tyr) and basic substrates (Fig. 2, see Supplementary Material Table 2). These features, which agree with the data obtained in parallel for the native placental hAPN, used as a reference control, and with those reported for PfA-M1 [25] and for porcine kidney APN, rat kidney APN and human kidney APN [23, 32], strongly suggest that these marine species contain 
enzymes that belong to the M1 family [1,3]. These results are in accordance with the presence of M1 family enzymes/sequences in closely related marine invertebrates belonging to Mollusca:Gastropoda, Echinodermata, Cnidaria:Anthozoa and Cnidaria:Hydrozoa [15,18-21,2931,33-35]. Additionally, this is the first biochemical evidence, based on kinetic results with a specific substrate, of the expression of M1 enzymes in these Caribbean species. The high degree of conservation of the alignment of human APN with marine invertebrate sequences, independently of the Phylum, agrees with the essential roles and multiple functions that APN display in all living organisms [1,3]. A direct association with the processing of endogenous peptides has been established for Aplysia californica neutral aminopeptidase [15]. Additionally, a L-Leu-aa hydrolyzing activity has also been detected in the digestive system of bivalves, such as Bathymodiolus thermophiles and Lucinoma aequizonata [34]. In Mytilus edulis, the neutral aminopeptidase activity is associated with the microvillous border (brush border) of the stomach, intestinal and digestive duct cells; increased salinity enhances its activity [36].

A preference for neutral and basic substrates is also observed for the cnidarian Physalia physalis, but in this case, the 9-10 optimal $\mathrm{pH}$ value is closer to that observed for mammalian M17 enzymes $[1,4]$. Additionally, except for the L. isodictyalis extract, in all other extracts, addition of cobalt increased L-Leu-pNA hydrolysis, strongly indicating that the hydrolysis could be due, at least in part, to the presence of M17 enzymes, suggesting that both M1 and M17 enzymes coexist in these species. These results are in perfect agreement with the existence of sequences for M17 enzymes in closely related species from Mollusca:Gastropoda, Echinodermata, Cnidaria:Anthozoa, Cnidaria:Hydrozoa and Porifera:Demospongiae, which were identified mainly by genomic, transcriptomic and/or proteomic approaches [20,21,29-31]. The high conservation degree observed in the alignment of M17 sequences in marine invertebrates, independently of the Phylum, agrees with the essential roles associated to intracellular protein turnover, a fundamental housekeeping process in all living organisms, in addition to other functions beyond aminopeptidase activity that have also been attributed to M17 family members [1,4]. Additionally, these results constitute the 
first biochemical evidences (using kinetic approach with specific substrate) for the expression of M17 enzymes in these Caribbean species.

Surprisingly, the activities from Lissodendoryx (Lissodendoryx) isodytyalis (Porifera) and Tripneustes ventricosus (Echinodermata) extracts were characterized by two ranges of optimal $\mathrm{pH}$ values with L-Leu-pNA as substrate, suggesting at least two different molecular entities. These extracts were also characterized by a higher rate of hydrolysis of L-Glu-AMC compared to other aaAMC substrates at $\mathrm{pH} 7.5$. In these two extracts, activities versus L-Glu-AMC at $\mathrm{pH} 7.5$ were independent of the concentration of calcium, indicating that they differ from the mammalian glutamyl aminopeptidase (APA), which needs calcium for activation. These extracts were also able to hydrolyze with good initial rates, basic and neutral substrates including L-Leu-AMC, suggesting the presence of M1 aminopeptidases, in agreement with the presence of M1 sequences in Echinodermata and Porifera:Demospongiae species [21,29]. This constitutes the first biochemical evidence (using kinetic approach) of this type of activity in these Caribbean species.

Since all extracts hydrolyzed L-Glu-AMC to some extent, and because in L. isodytyalis and T. ventricosus extracts L-Glu-AMC activities were independent of calcium, we tested the effect of cobalt on the hydrolysis of L-Glu-pNA at $\mathrm{pH} 7.5$, an indicator of the M18 family $[1,8,12,37,38]$. The addition of $1 \mathrm{mM}$ cobalt in the assay buffer increased the hydrolysis of L-Glu-pNA by at least 10 percent. Additionally, bestatin $100 \mu \mathrm{M}$ did not modify the hydrolysis rate. On the contrary, we observed, in parallel assays, that pAPA (M1 family) activity was inhibited by bestatin and cobalt. These data strongly suggest that the glutamyl aminopeptidase activities detected in Nerita peloronta, Nerita versicolor, Lissodendoryx (Lissodendoryx) isodictyalis, Tripneustes ventricosus, Echinaster (Othilia) echinophorus, Stichodactyla helianthus, Bunodosoma granuliferum and Physalia physalis do not belong to the M1 family, but rather to the M18 family, since the stimulatory effect of cobalt, and the insensitivity to inhibition by bestatin, are properties of M18 enzymes from Plasmodium to mammals $[1,8,12,38]$. These results are in perfect agreement with previous reports, using genomic, transcriptomic and/or proteomic approaches, of M18 sequences in 
the marine species Mollusca:Gastropoda, Cnidaria:Anthozoa, Cnidaria:Hydrozoa and Porifera:Demospongiae [20,21,30,31]. Unlike neutral aminopeptidases, few M18 aminopeptidases have been biochemically characterized; those derived from human [8,9], yeast [39] and Plasmodium falciparum [38]. Based on their restricted specificities for the N-terminal acidic amino acids, which cannot be cleaved by other aminopeptidases, it is proposed that they can act in concert with other aminopeptidases to facilitate protein turnover and peptide metabolism. In humans, a more specific function in the conversion of angiotensin II to the vasoactive angiotensin III in the central nervous system has been implicated [40]. This is the first report of a biochemical characterization (based on a kinetic approach with a specific substrate) of M18 enzymes in these marine Caribbean invertebrates, and the first evidence for Echinodermata species.

Aminopeptidase expression is crucial for healthy cells but aminopeptidases are also markers in some diseases $[3,4,7]$. Thus, methods to rapidly identify them in complex biological samples are welcome. These methods can allow in depth clarification of physio- and pathophysio-logical processes, when the relevance of these enzymes remains unclear. In the present contribution, we combined the well-established screening of a substrate library of natural and/or unnatural aminoacids $[23,32,41,42,43]$ with the use of inhibitors and ions, to identify the specific type of aminopeptidase expressed by Cuban marine invertebrates. Specifically, we proposed a kinetic approach that combines substrate specificity and discrimination of M1 vs M17 family, according to cobalt effect on hydrolysis of L-Leu (M1 inhibited, M17 activated). This general approach should facilitate the identification of M1 and/or M17 enzymes in complex biological samples. Additionally, we proposed the use of calcium, cobalt, and bestatin, to distinguish if hydrolysis of LGlu is due to a M1 or M18 family enzyme. If hydrolysis of L-Glu is activated by calcium, inhibited by cobalt and by micromolar bestatin, the aminopeptidase probably belongs to the M1 family. If the hydrolysis of L-Glu is not susceptible to calcium, activated by cobalt, and not inhibited by bestatin, the aminopeptidase is probably of the M18 family.

\section{Conclusion}


In conclusion, using a biochemical kinetic approach combining substrate specificity and sensitivity to ions and inhibitors, we demonstrate that aqueous extracts from Caribbean invertebrate species belonging to the Phyla Mollusca, Porifera, Echinodermata and Cnidaria contain metalloaminopeptidase activities alike those of the M1, M17 and M18 families. This is the first evidence for M18-like activities in Echinodermata species.

Acknowledgments: The authors thank the IUBMB Mid-Career fellowship program (research of IPA at IF and JLC laboratories) and the French ANR project MAMMAMIA "design of potential antiMAlarial M1/M17 AMinopeptiIdase Agents”, 2012-2017. We also thank Prof. Jose Espinosa, from the National Institute of Oceanology, CITMA, Cuba, who kindly provided species pictures included in Fig. 1 and in Supplementary Material, Fig. 2.

\section{References}

1. Rawlings ND, Barrett AJ, Thomas PD, Huang X, Bateman A, Finn RD. The MEROPS database of proteolytic enzymes, their substrates and inhibitors in 2017 and a comparison with peptidases in the PANTHER database. Nucleic Acids Res 2018;46:D624- D632.

2. Bogyo M. Introduction to the special issue on proteases and proteolysis in health and disease. FEBS J 2017; 284:1392-93.

3. Drinkwater N, Lee J, Yang W, Malcolm TR, McGowan S. M1 aminopeptidases as drug targets: broad applications or therapeutic niche?. FEBS J 2017;284:1473-88.

4. Drinkwater N, Malcolm TR, McGowan S. M17 aminopeptidases diversify function by moderating their macromolecular assemblies and active site environment. Biochimie 2019;166:3851.

5. Wong A, Zhou D, Rini J M. The X-ray crystal structure of human Aminopeptidase N reveals a novel dimer and the basis for peptide processing. J Biol Chem 2012;44:36804-813. 
6. Chen L, Ling Y L, Peng G, Li F. Structural basis for multifunctional roles of mammalian aminopeptidase N. Proc Natl Acad Sci USA 2012;44:17966-71.

7. Amin A, Adhikari N, Jha T. Design of aminopeptidase N (APN) inhibitors as anticancer agents. J Med Chem 2018;61:6468-90.

8. Wilk S, Wilk E, Magnusson RP. Purification, characterization, and cloning of a cytosolic aspartyl aminopeptidase. J Biol Chem 1998;273:15961-70.

9. Chaikuad A, Pilka ES, De Riso A, von Delft F, Kavanagh KL, Vénien-Bryan C, et al. Structure of human aspartyl aminopeptidase complexed with substrate analogue: insight into catalytic mechanism, substrate specificity and M18 peptidase family. BMC Struct Biol 2012;12:14.

10. Goldberg DE. Complex nature of malaria parasite hemoglobin degradation. Proc Natl Acad Sci USA 2013;110:5283-84.

11. Skinner-Adams TS, Stack CM, Trenholme KR, Brown CL, Grembecka J, Lowther J, et al. Plasmodium falciparum neutral aminopeptidases: new targets for anti-malarials. Trends Biochem Sci 2010;35:53-61.

12. Teuscher F, Lowther J, Skinner-Adams TS, Spielmann T, Dixon MW, Stack CM, et al. The M18 aspartyl aminopeptidase of the human malaria parasite Plasmodium falciparum. J Biol Chem 2007;282:30817-26.

13. Alonso del Rivero M, Trejo S, Rodríguez de la Vega M, González Y, Bronsoms S, Canals F, et al. A novel metallocarboxypeptidase like enzyme isolated from the marine annelid Sabellastarte magnifica - a step into the invertebrate world of proteases. FEBS J 2009;276:4875-90.

14. Bauer BA, Eitenmiller RR. Muscle arylamidase activity of several marine species. J Fish Res Board Can 1974;31:445.

15. Bawab W, Querido E, Crine $\mathrm{Ph}$, Desgroseillers L. Identification and characterization of aminopeptidases from Aplysia californica. Biochem J 1992;286:967-75. 
16. Pascual I, Sh G, Cisneros M, Joseph-Bravo P, Diaz J, Possani L, et al. Purification of a specific inhibitor of pyroglutamyl aminopeptidase II from the marine annelide Hermodice carunculata: In vivo effects in rodent brain. Int J Biochem Cell Biol 2004;36:138-52.

17. Shim JS, Lee H S, Shin J, Kwon HJ. Psammaplin A, a marine natural product, inhibits aminopeptidase $\mathrm{N}$ and suppresses angiogenesis in vitro. Cancer Lett 2004;3:163-69.

18. Wickham L, Zappulla JPh, DesGroseillers L. Molecular cloning, sequence analysis and expression distribution of an aminopeptidase in Aplysia californica. Comp Biochem Physiol B 1999;124:429-37.

19. Sokolova IM, Boulding EG. Length polymorphisms in an intron of aminopeptidase $\mathrm{N}$ provide a useful nuclear DNA marker for Littorina species (caenogastropoda). J Mol Stud 2004;70:165-72.

20. Putnam NH, Srivastava M, Hellsten U, Dirks B, Chapman J, Salamov A, et al. Sea anemone genome reveals ancestral Eumetazoan gene repertoire and genomic organization. Science 2007;317:86-94.

21. Srivastava M, Simakov O, Chapman J, Fahey B, Gauthier M E, Mitros T, et al. The Amphimedon queenslandica genome and the evolution of animal complexity. Nature 2010;466:72026.

22. Pascual I, Bounaadja L, Sánchez L, Rivera L, Tarnus C, Schmitt M, et al. Aqueous extracts of marine invertebrates from Cuba coastline display neutral aminopeptidase inhibitory activities and effects on cancer cells and Plasmodium falciparum parasites. Ind J Nat Prod Res 2017; 8:107-19.

23. Byzia A, Szeffler A, Kalinowski L, Drag M. Activity profiling of aminopeptidases in cell lysates using a fluorogenic substrate library. Biochimie 2016;122:31-7.

24. Scopes R. Protein purification: principles and practice, Springler-Verlag Series, 329-469. 1987.

25. Allary M, Schrével JA, Florent I. Properties, stage-dependent expression and localization of Plasmodium falciparum M1 family zinc-aminopeptidase. Parasitology 2002;125:1-10. 
26. Thompson JD, Higgins DG, Gibson TJ. CLUSTAL W: improving the sensitivity of progressive multiple sequence alignment through sequence weighting, position-specific gap penalties and weight matrix choice. Nucleic Acids Res 1994;22:4673-80.

27. Glaser F, Pupko T, Paz I, Bell RE, Bechor-Shental D, Martz E, et al. ConSurf: identification of functional regions in proteins by surface-mapping of phylogenetic information. Bioinformatics 2003;19:163-64

28. Stack CM, Lowther J, Cunningham E, Donnelly Sh, Gardiner DL, Trenholme KR, et al. Characterization of the Plasmodium falciparum M17 leucyl aminopeptidase: a protease involved in amino acid regulation with potential for antimalarial drug development. J Biol Chem 2007;282:2069-80.

29. Sodergren E, Weinstock GM, Davidson EH, Cameron RA, Gibbs RA, Angerer RC, et al. (Sea Urchin Genome Sequence Consortium). The genome of the sea urchin Strongylocentrotus purpuratus. Science 2006; 314: 941-952.

30. Wenger I, Galliot B. Punctuated emergences of genetic and phenotypic innovations in eumetazoan, bilaterian, euteleostome, and hominidae ancestors. Genome Biol Evol 2013;5:1949-68. 31. Bulat T, Smidak R, Sialana FJ, Jung G, Rattei Th, Bilban M, et al. Transcriptomic and proteomic analysis of Arion vulgaris—-Proteins for probably successful survival strategies? PLOS ONE 2016;11:e0150614.

32. Drag M, Bogyo M, Ellman JA, Salvesen GS. Aminopeptidase fingerprints, an integrated approach for identification of good substrates and optimal inhibitors. J Biol Chem 2010;285:331018.

33. Young JPW, Koehn RK, Arnheim N. Biochemical characterization of "LAP," a polymorphic aminopeptidase from the blue mussel, Mytilus edulis. Biochem Gen 1979;3/4:305-23.

34. Boetius A, Felbeck H. Digestive enzymes in marine invertebrates from hydrothermal vents and other reducing environments. Marine Biol I995;122:105-13. 
35. Umetsu H, Araia M, Otab T, Kudob R, Sugiurab H, Ishiyamab H, et al. Purification and properties of an aminopeptidase from the mid-gut gland of scallop (Patinopecten yessoensis). Comp Biochem Physiol B 2003;136:935-42.

36. Moore MN, Koehn RK, Bayne B. Leucine aminopeptidase (Aminopeptidase-I), N-acetyl-Phexosaminidase and lysosomes in the mussel, Mytilus edulis L., in response to salinity changes. $\mathbf{J}$ Exp Zool 1980;214:239-49.

37. Tieku T, Hooper M. Inhibition of aminopeptidases N, A and W: a re-evaluation of the actions of bestatin and inhibitors of angiotensin converting enzyme. Biochem Pharmacol 1992;44:1725-30.

38. Sivaraman KK, Oellig CA, Huynh K, Atkinson SC, Poreba M, Perugini MA, et al. X-ray crystal structure and specificity of the Plasmodium falciparum malaria aminopeptidase PfM18AAP. J Mol Biol 2012;422:495-507.

39. Yokoyama R1, Kawasaki H, Hirano H. Identification of yeast aspartyl aminopeptidase gene by purifying and characterizing its product from yeast cells. FEBS J 2006;273:192-8.

40. Wright JW, Harding JW. Important role for angiotensin III and IV in the brain renin-angiotensin system. Brain Res Brain Res Rev 1997; 25:96-124.

41. Poreba M, McGowan S, Skinner-Adams TS, Trenholme KR, Gardiner DL, Whisstock JC, To J, Salvesen GS, Dalton JP, Drag M. Fingerprinting the substrate specificity of M1 and M17 aminopeptidases of human malaria, Plasmodium falciparum. PLoS One 2012;7:e31938.

42. Poreba M, Gajda A, Picha J, Jiracek J, Marschner A, Klein CD, Salvesen GS, Drag M. S1 pocket fingerprints of human and bacterial methionine aminopeptidases determined using fluorogenic libraries of substrates and phosphorus-based inhibitors. Biochimie 2012;94:704-10

43. Byzia A, Haeggström JZ, Salvesen GS, Drag M. A remarkable activity of human leukotriene A4 hydrolase (LTA4H) toward unnatural amino acids. Amino Acids 2014; 46:1313-20 


\section{Figure legends}

Figure 1: Characterization of neutral aminopeptidase-like activities from crude aqueous extracts from Echinaster echinophorus and Stichodactyla helianthus. (A) and (B): dose-response curves for the inhibition by bestatin $(0.05-50 \mu \mathrm{M})$ of the neutral aminopeptidase-like enzymes detected in crude aqueous extracts from Echinaster echinophorus and Stichodactyla helianthus, respectively. Individual data are represented as residual activity (RA, fraction of the control assay) vs bestatin concentration in the assay. (C) and (D) Michaelis-Menten behavior versus L-Leu-AMC (10-500 $\mu \mathrm{M})$ of the neutral aminopeptidase-like activities detected in crude aqueous extracts from Echinaster echinophorus and Stichodactyla helianthus, respectively. Data are represented in terms of initial rate vs L-Leu-AMC concentration. The protein concentration in the kinetic assays was: Echinaster (Othilia) echinophorus $(0.07 \mathrm{mg} / \mathrm{mL})$ and Stichodactyla helianthus $(0.42 \mathrm{mg} / \mathrm{mL})$. Pictures were kindly supplied by Professor Jose Espinosa, PhD, from the National Institute of Oceanology, CITMA, Cuba.

Figure 2: Summary of the hydrolysis rates at $\mathrm{pH} 7.5$ of L-aminoacyl-AMC substrates by aqueous crude extracts from marine species, and by the control metallo-aminopeptidases hAPN, PfA-M1 and rPfA-M17. L-aa-AMC substrates were tested at $100 \mu \mathrm{M}$. Results are mean of 2 experiments expressed as percentage of initial rate of hydrolysis normalized to that of the substrate with the highest value taken as 100\%. Data for PfA-M1 are from [25] taking Lys-AMC hydrolysis as 100\%. (A) Np: Nerita peloronta, (B) Nv: Nerita versicolor, (C) Li: Lissodendoryx (Lissodendoryx) isodictyalis, (D) Tv: Tripneustes ventricosus, (E) Ee: Echinaster (Othilia) echinophorus, (F) Sh: Stichodactyla helianthus, (G) Bg: Bunodosoma granuliferum, (H) Pp: Physalia physalis.

Figure 3: Multiple sequence alignment of representative sequences belonging to the aminopeptidase M1 family in marine invertebrates. The MSA was carried out using ClustalW [26]. For clarity, we present only one sequence per organism. We show the canonical sequences 
${ }^{352} \underline{\mathrm{GxMEN}}^{356}$ (red font) and ${ }^{385} \underline{\mathrm{abxHEbbHbcx}} 16 \underline{\mathrm{E}}^{411}$, where ' $\mathrm{x}$ ' is any amino acid, 'a' is most often valine or threonine, 'b' is an uncharged residue, and 'c' a hydrophobic residue. The conservation grade ranged from 1 (variable) to 9 (conserved) and was calculated in the Consurf server [27] using as input the MSA of all sequences (Supplementary Material Table 3). Uniprot codes: Homo sapiens (P15144), Littorina obtusata (Q6UZ69), Littorina plena (Q6UZ70), Littorina saxatilis (Q6UZ67), Littorina scutulata (Q6UZ71), Littorina sitkana (Q6UZ53), Littorina subrotundata (Q6UZ63), Arion vulgaris (A0A0B7AVU0), Aplysia californica (Q9U0D1), Lottia gigantea (V4AT03), Haliotis discus hannai (A0A1I9W307), Strongylocentrotus purpuratus (W4ZH25), Nematostella vectensis (A7S394), Hydra vulgaris (T2MFK7), and Amphimedon queenslandica (A0A1X7V0N8). Residue numbers are for the human sequence.

Figure 4: Multiple sequence alignment of representative sequences belonging to aminopeptidase M17 and M18 families in marine invertebrates. The MSA was carried out using ClustalW [26]. For clarity, we present only one sequence per organism. The conservation grade ranged from 1 (variable) to 9 (conserved) and was calculated in the Consurf server [27] using as input the MSA of all sequences (Supplementary Material Tables 4 and 5). Residue numbers are for the human sequence. (A) Aminopeptidase M17 family. We show amino acids involved in catalysis and metal coordination and the canonical sequence ${ }^{362} \underline{\text { NTDAEGR }}^{368}$ (red font). Uniprot codes: Homo sapiens (P28838), Lottia gigantea (V3ZPM6), Arion vulgaris (A0A0B7AAC1), Strongylocentrotus purpuratus (W4ZBD0), Nematostella vectensis (A7SX56), Hydra vulgaris (T2M8Q9), and Amphimedon queenslandica (A0A1X7V5U6). (B) Aminopeptidase M18 family. We show the amino acids involved in catalysis and metal coordination. Uniprot codes: Homo sapiens (Q9ULA0), Lottia gigantea (V3Z7I6), Arion vulgaris (A0A0B7ACW1), Nematostella vectensis (A7RHL4), Hydra vulgaris (T2M3F8), and Amphimedon queenslandica (A0A1X7UM67, A0A1X7T6D9). 


\section{Supplementary Material}

\section{Biochemical evidences for M1-, M17- and M18-likeaminopeptidases in marine invertebrates from Cuban coastline}

Isel Pascual Alonso ${ }^{\mathrm{a}^{*}}$, Laura Rivera ${ }^{\mathrm{a}}$, Mario E. Valdés-Tresanco ${ }^{\mathrm{a}, \mathrm{b}}$, Lotfi Bounaadja ${ }^{\mathrm{c}}$, Marjorie Schmitt ${ }^{\mathrm{d}}$, Yarini Arrebola ${ }^{1}$, Luis Alvarez Lajonchere ${ }^{\mathrm{e}}$, Jean-Louis Charlif ${ }^{\mathrm{f}} \&$ Isabelle Florent ${ }^{\mathrm{c}}$

${ }^{a}$ Center for Protein Studies, Faculty of Biology, University of Havana, Havana, Cuba; ${ }^{b}$ Department of Biological Sciences, University of Calgary, 2500 University Dr. NW Calgary, Alberta, Canada T2N 1N4; 'Molécules de Communication et Adaptation des Microorganismes (MCAM, UMR 7245), Sorbonne Universités, Muséum National d'Histoire Naturelle, CNRS, CP52, 57 rue Cuvier 75005 Paris, France; 'Laboratoire d'Innovation Moléculaire et Applications - Université de HauteAlsace, Université de Strasbourg, CNRS, LIMA UMR7042, F-68100 Mulhouse, France ; ${ }^{e}$ Museo de Historia Natural "Felipe Poey"; Faculty of Biology, University of Havana, Cuba; ${ }^{\text {Instituto de }}$ Biotecnología, Universidad Nacional Autónoma de México (UNAM), Ave Universidad 2001, Cuernavaca, Morelos, México.

*Corresponding author: Isel Pascual, PhD. Center for Protein Studies, Faculty of Biology, University of Havana, Cuba. 25 \# 455, between J and I, Plaza de la Revolución, Havana, Cuba, CP 10 400. Email: isel@ fbio.uh.cu, Tel. +53 (7) 8324830, Fax: +53 (7) 8321321 


\begin{abstract}
Metallo-aminopeptidases (mAPs) control many physiological processes. They are classified in different families according to structural similarities. Neutral mAPs catalyze the cleavage of neutral amino acids from the N-terminus of proteins or peptide substrates; they need one or two metallic cofactors in their active site. Information about marine invertebrate's neutral mAPs properties is scarce; available data are mainly derived from genomics and cDNA studies. The goal of this work was to characterize the biochemical properties of the neutral APs activities in eight Cuban marine invertebrate species from the Phyla Mollusca, Porifera, Echinodermata, and Cnidaria. Determination of substrate specificity, optimal $\mathrm{pH}$ and effects of inhibitors and ions (1,10-phenanthroline, cobalt, amastatin and bestatin) on activity led to the identification of neutral AP-like activities, whose biochemical behaviors were similar to those of the M1 and M17 families of mAPs. Additionally, M18-like glutamyl AP activities were detected. Thus, marine invertebrates express biochemical activities likely belonging to various families of metallo-aminopeptidases.
\end{abstract}

\title{
Keywords
}

Metallo-aminopeptidase; marine invertebrate; M1 family; M17 family; M18 family 
Table 1 SM. Marine invertebrate's species from the Havana coastline studied in the present contribution.

\begin{tabular}{ll}
\hline Species & Phyla: Class: Family \\
\hline Nerita peloronta (Linnaeus, 1758) & Mollusca: Gastropoda: Neritidae \\
Nerita versicolor (Gmelin, 1791) & Mollusca: Gastropoda: Neritidae \\
Lissodendoryx (Lissodendoryx)isodictyalis (Carter, 1882) & Porifera: Demospongiae: Coelosphaeridae \\
Tripneustes ventricosus (Lamarck, 1816) & Echinodermata: Echinoidea: Toxopneustidae \\
Echinaster (Othilia) echinophorus (Lamarck, 1816) & Echinodermata: Asteroidea: Echinasteridae \\
Stichodactyla helianthus (Ellis, 1768) & Cnidaria: Anthozoa: Stichodactylidae \\
Bunodosoma granuliferum (Le Sueur, 1817) & Cnidaria: Anthozoa: Actiniidae \\
Physalia physalis (Linnaeus, 1758) & Cnidaria: Hydrozoa: Physaliidae \\
\hline
\end{tabular}

Species names were validated on the reference WORMS database (http://www.marinespecies.org/index.php). 

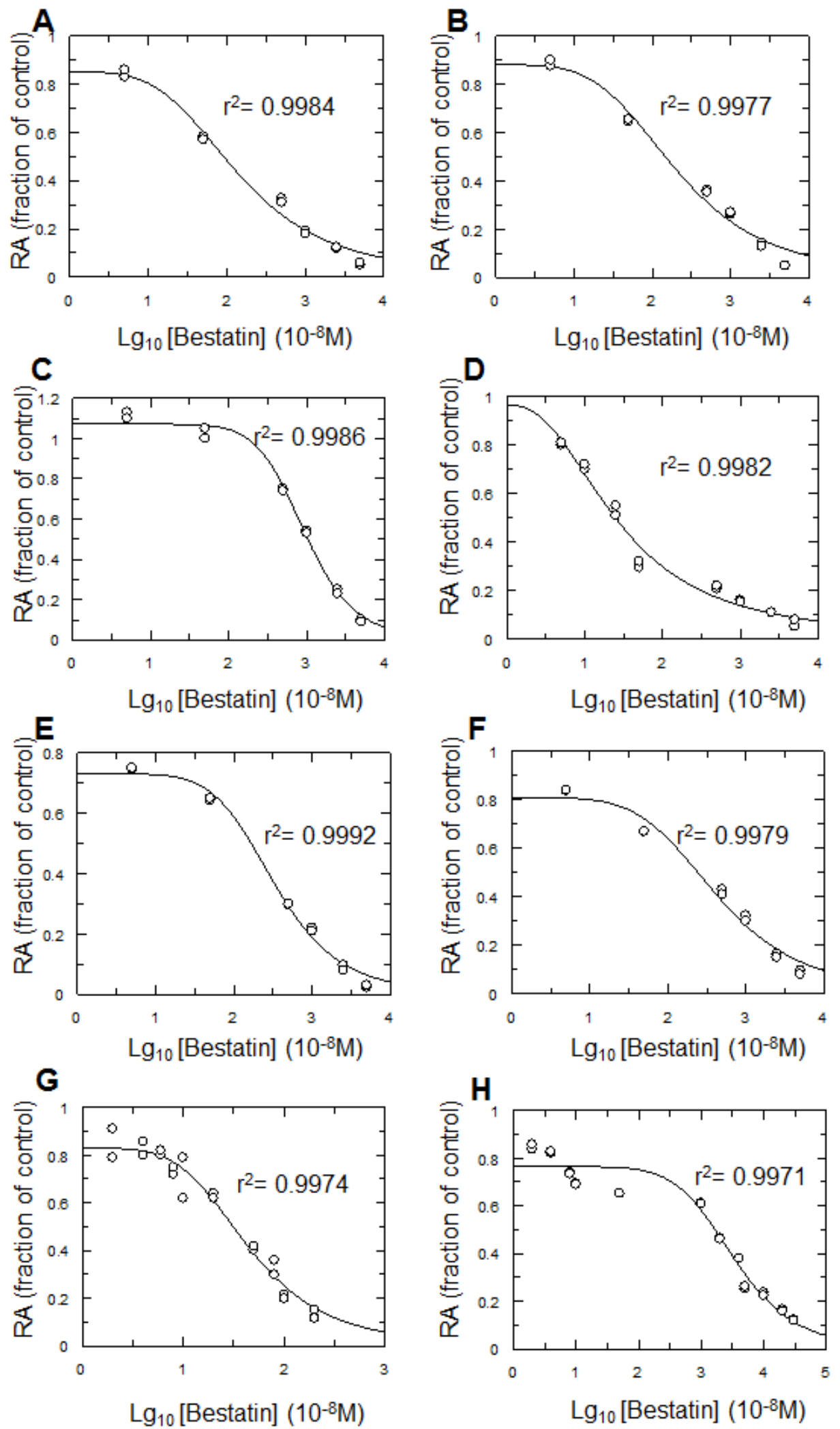

Figure $1 \mathrm{SM}$. Dose-response curves for the inhibition by bestatin $(0.05-50 \mu \mathrm{M})$ of the neutral aminopeptidase-like enzymes detected in crude aqueous extracts from marine invertebrates. These assays were done in $\mathrm{Tris} \mathrm{HCl} 50$ $\mathrm{mM} \mathrm{pH} \mathrm{7.5,} \mathrm{with} \mathrm{a} \mathrm{fixed} \mathrm{amount} \mathrm{of} \mathrm{each} \mathrm{crude} \mathrm{extract} \mathrm{inside} \mathrm{the} \mathrm{linear} \mathrm{range} \mathrm{of} \mathrm{initial} \mathrm{rate,} \mathrm{in} \mathrm{a} \mathrm{final} \mathrm{assay} \mathrm{volume} \mathrm{of}$ $200 \mu \mathrm{L}$. Each aqueous crude extract was preincubated for $30 \mathrm{~min}$ with bestatin prior to the addition of L-Leu-AMC at $0.025 \mathrm{mmol} / \mathrm{L}$. A: Nerita peloronta $(0.42 \mathrm{mg} / \mathrm{mL})$, B: Nerita versicolor $(0.29 \mathrm{mg} / \mathrm{mL})$, C: Tripneuste ventricosus $(0.74$ $\mathrm{mg} / \mathrm{mL})$, D: Echinaster echinophorus $(0.07 \mathrm{mg} / \mathrm{mL})$, E: Stichodactyla helianthus $(0.42 \mathrm{mg} / \mathrm{mL})$, F: Bunodosoma granulifera $(0.09 \mathrm{mg} / \mathrm{mL}), \mathrm{G}$ : rPfA-M17 $(280 \mathrm{nM}), \mathrm{H}$ : hAPN $(0.25 \mathrm{mg} / \mathrm{mL})$. 
A

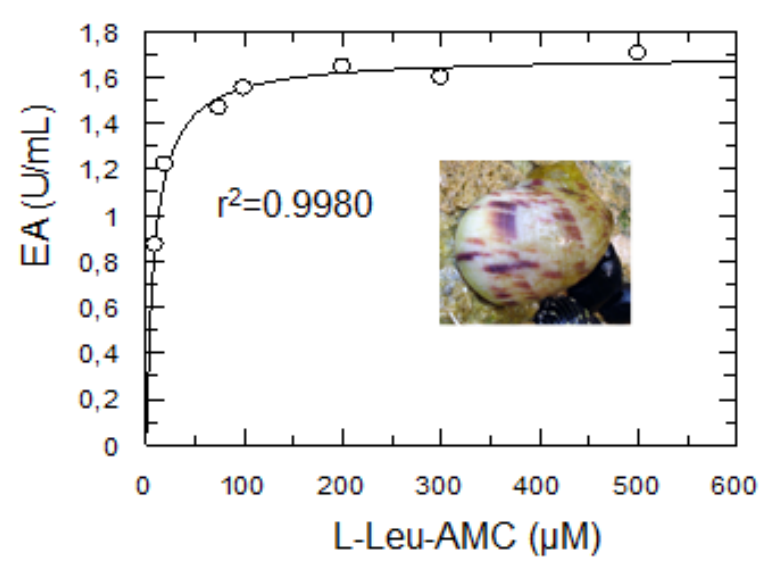

C

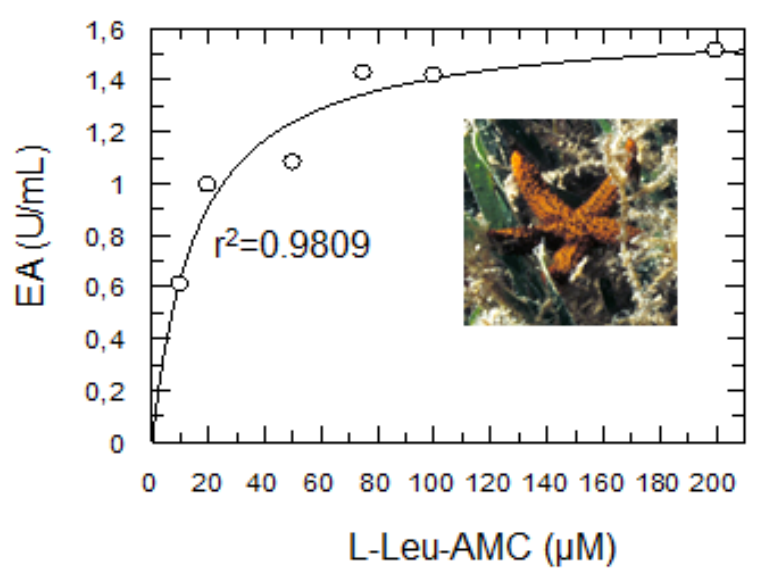

E

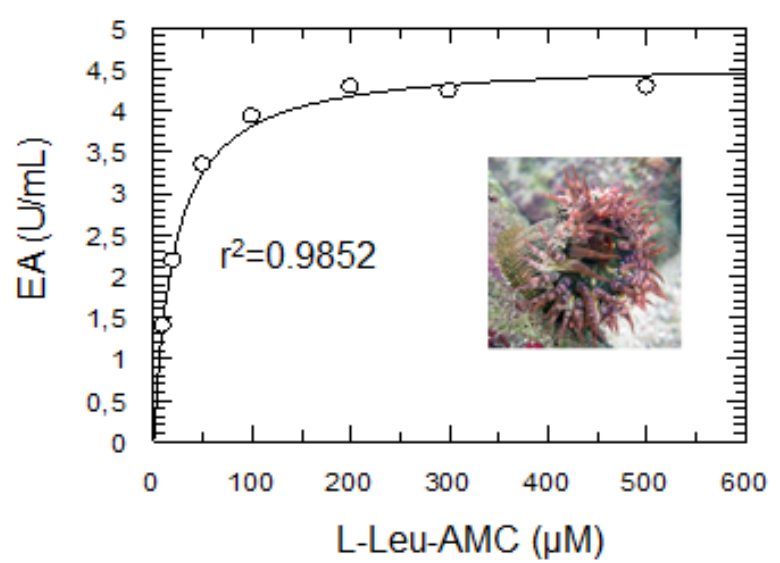

B
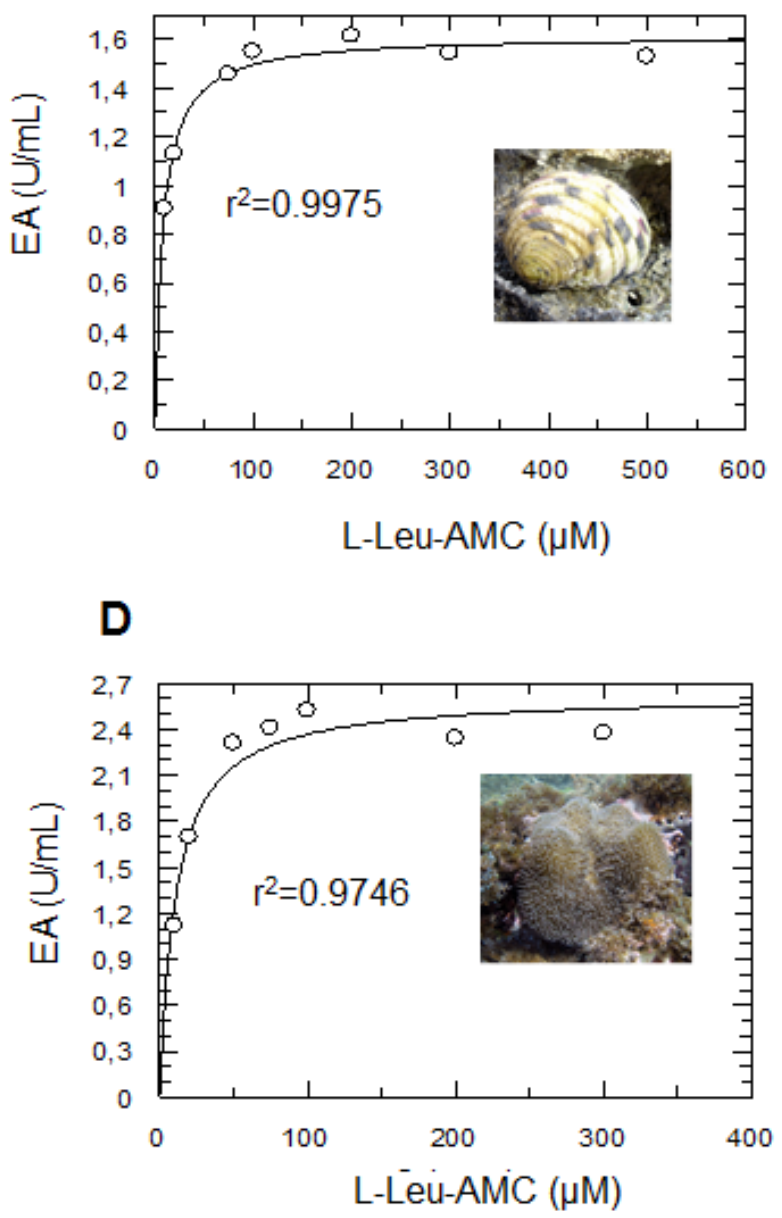

$\mathbf{F}$

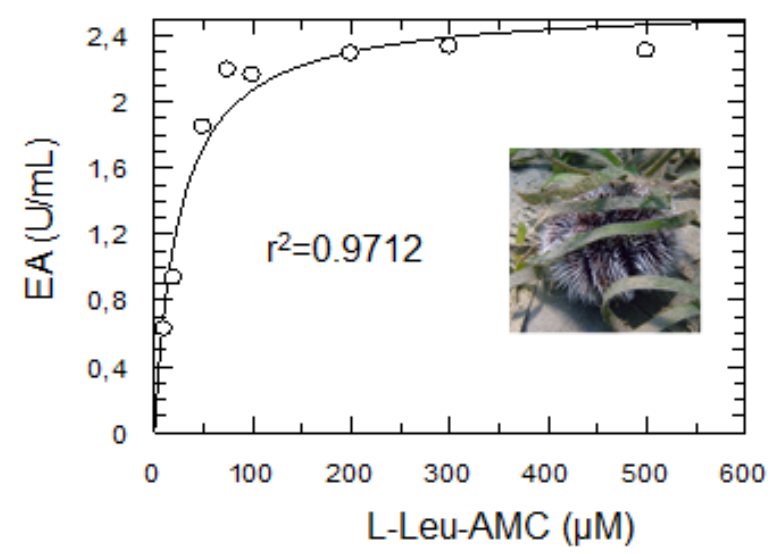

Figure 2 SM. Michaelis-Menten behavior versus L-Leu-AMC (10-500 $\mu \mathrm{M})$ of the neutral aminopeptidase-like activities detected in crude aqueous extracts from marine invertebrates. These assays were done in Tris $\mathrm{HCl} 50$ $\mathrm{mM} \mathrm{pH} \mathrm{7.5,} \mathrm{with} \mathrm{a} \mathrm{fixed} \mathrm{amount} \mathrm{of} \mathrm{each} \mathrm{crude} \mathrm{extract} \mathrm{inside} \mathrm{the} \mathrm{lineal} \mathrm{range} \mathrm{of} \mathrm{initial} \mathrm{rate,} \mathrm{in} \mathrm{a} \mathrm{final} \mathrm{assay} \mathrm{volume} \mathrm{of}$ $200 \mu$ L. A: Nerita peloronta $(0.42 \mathrm{mg} / \mathrm{mL})$, B: Nerita versicolor $(0.29 \mathrm{mg} / \mathrm{mL}$ ), C: Echinaster (Othilia) echinophorus $(0.07 \mathrm{mg} / \mathrm{mL})$, D: Stichodactyla helianthus $(0.42 \mathrm{mg} / \mathrm{mL})$, E: Bunodosoma granuliferum $(0.09 \mathrm{mg} / \mathrm{mL})$, F: Tripneustes ventricosus $(0.74 \mathrm{mg} / \mathrm{mL})$. Pictures were kindly supplied by Professor Jose Espinosa, $\mathrm{PhD}$, from the National Institute of Oceanology, CITMA, Cuba. 
Table 2 SM. Substrate specificity for each extract, and control aminopeptidases, according to decreasing order of initial rate based in Figure 2.

\begin{tabular}{|c|c|c|c|c|c|c|c|c|c|}
\hline $\mathrm{Np}$ & Phe & Ala & Leu & Tyr & Arg & Glu & Ser & Asn & Asp \\
\hline $\mathrm{Nv}$ & Phe & Ala & Leu & Arg & Tyr & Glu & Asp & Ser & Asn \\
\hline $\mathrm{Li}$ & Glu & Ala & Phe & Ser & Tyr & Asn & Arg & Leu & Asp \\
\hline $\mathrm{Tv}$ & Glu & Phe & Arg & Leu & Ala & Tyr & Asn & Ser & - \\
\hline $\mathrm{Ee}$ & Leu & Arg & Ala & Phe & Tyr & Asn & Ser & Glu & - \\
\hline Sh & Phe & Tyr & Ala & Leu & Arg & Ser & Glu & Asn & - \\
\hline $\mathrm{Bg}$ & Leu & Arg & Phe & Ala & Tyr & Glu & Ser & Asn & - \\
\hline $\mathrm{Pp}$ & Ala & Leu & Arg & Phe & Tyr & Glu & Ser & Asn & - \\
\hline hAPN & Leu & Ala & Arg & Phe & Tyr & Ser & Asn & - & - \\
\hline PfA-M1 & Ala & Arg & Leu & Phe & Tyr & Asn & Ser & - & - \\
\hline rPfA-M17 & Leu & Phe & - & - & - & - & - & - & - \\
\hline
\end{tabular}

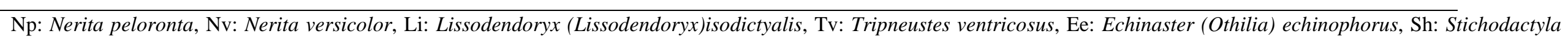
helianthus, Bg: Bunodosoma granuliferum, Pp: Physalia physalis. 
1 Table 3 SM. UNIPROT ID, Species and Taxonomy of all entries of the M1 family used for MSA.

\begin{tabular}{|c|c|c|}
\hline UNIPROT ID & Species & Taxonomy \\
\hline$\underline{\mathrm{P} 15144}$ & Homo sapiens & $\begin{array}{l}\text { Eukaryota; Metazoa; Chordata; Craniata; Vertebrata; } \\
\text { Euteleostomi;Mammalia; Eutheria; Euarchontoglires; } \\
\text { Primates; Haplorrhini; Catarrhini; Hominidae; Homo }\end{array}$ \\
\hline Q6UZ69 & Littorina obtusata & \\
\hline Q6UZ70 & Littorina plena & \\
\hline $\begin{array}{l}\text { Q6UZ67; Q6UZ65 } \\
\text { Q6UZ68; Q6UZ66 }\end{array}$ & Littorina saxatilis & Fukarvota $\cdot$ Metazog $\cdot$ Lonhotrochozoa $\cdot$ Mollusca. \\
\hline Q6UZ71 & Littorina scutulata & $\begin{array}{c}\text { Gastropoda; Caenogastropoda; Hypsogastropoda; } \\
\text { Littorinimorpha; Littorinoidea; Littorinidae; Littorina. }\end{array}$ \\
\hline $\begin{array}{l}\text { Q6UZ53; Q6UZ75 } \\
\text { Q6UZ52; Q6UZ74 }\end{array}$ & Littorina sitkana & \\
\hline $\begin{array}{l}\text { Q6UZ63; Q6UZ64 } \\
\text { Q6UZ62; Q6UZ57 } \\
\text { Q6UZ58; Q6UZ60 } \\
\text { Q6UZ72; }\end{array}$ & Littorina subrotundata & \\
\hline $\begin{array}{l}\text { A0A0B7AVU0; } \\
\text { A0A0B7AIS9; } \\
\text { A0A0B7AIS9; } \\
\text { A0A0B7BBW7 } \\
\text { Q9U0D1 }\end{array}$ & Aplysia californica & $\begin{array}{c}\text { Eukaryota; Metazoa; Lophotrochozoa; Mollusca; } \\
\text { Gastropoda; Heterobranchia; Euthyneura; } \\
\text { Panpulmonata; Eupulmonata; Stylommatophora; } \\
\text { Sigmurethra; Arionoidea; Arionidae; Arion. } \\
\text { Eukaryota; Metazoa; Lophotrochozoa; Mollusca; } \\
\text { Gastropoda; Heterobranchia; Euthyneura; } \\
\text { Euopisthobranchia; Aplysiomorpha; Aplysioidea; } \\
\text { Aplysiidae; Aplysia. }\end{array}$ \\
\hline $\begin{array}{l}\text { V4AT03; V3ZTC8 } \\
\text { V4AZ53; V4CEL3 } \\
\text { V4CEL6; V4AU50 } \\
\text { V4BLS2; V3ZAN6 } \\
\text { V4AGZ2 }\end{array}$ & Lottia gigantea & $\begin{array}{c}\text { Eukaryota; Metazoa; Lophotrochozoa; Mollusca; } \\
\text { Gastropoda; Patellogastropoda; Lottioidea; Lottiidae; } \\
\text { Lottia. }\end{array}$ \\
\hline$\underline{\mathrm{A} 0 \mathrm{~A} 1 \mathrm{I} 9 \mathrm{~W} 307}$ & Haliotis discus hannai & $\begin{array}{c}\text { Eukaryota; Metazoa; Lophotrochozoa; Mollusca; } \\
\text { Gastropoda; Vetigastropoda; Haliotoidea; Haliotidae; } \\
\text { Haliotis. }\end{array}$ \\
\hline W4ZH25; W4XIN9 & & \\
\hline $\begin{array}{l}\text { W4XXN4; Q29VH4 } \\
\text { W4ZL24; W4Y982 } \\
\text { W4YHU2; W4Z6D1 } \\
\text { W4Y430; W4YIX9 } \\
\text { W4YD32; W4Y8B9 } \\
\text { A7S394; A7S5H5 } \\
\text { A7SCU3; A7SCT9 } \\
\text { A7RL33; A7SLF6 } \\
\text { A7S604; A7TCI3 } \\
\text { A7RUV9 }\end{array}$ & $\begin{array}{c}\text { Strongylocentrotus } \\
\text { purpuratus }\end{array}$ & $\begin{array}{l}\text { Eukaryota; Metazoa; Echinodermata; Eleutherozoa; } \\
\text { Echinozoa; Echinoidea; Euechinoidea; Echinacea; } \\
\text { Echinoida; Strongylocentrotidae; Strongylocentrotus. }\end{array}$ \\
\hline 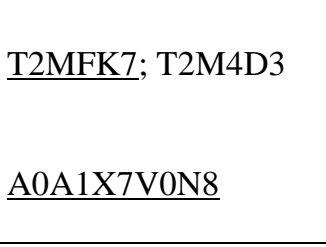 & $\begin{array}{c}\text { Hydra vulgaris } \\
\text { Amphimedon queenslandica }\end{array}$ & $\begin{array}{c}\text { Eukaryota; Metazoa; Cnidaria; Hydrozoa; } \\
\text { Hydroidolina; Anthoathecata; Aplanulata; Hydridae; } \\
\text { Hydra. } \\
\text { Eukaryota; Metazoa; Porifera; Demospongiae; } \\
\text { Heteroscleromorpha; Haplosclerida; Niphatidae; } \\
\text { Amphimedon. }\end{array}$ \\
\hline
\end{tabular}


3 The UNIPROT IDs of the sequences used for MSA in figure 2 in the main manuscript have been underlined. The common 4 taxonomic category between the organisms of the Caribbean Sea and the organisms containing aminopeptidases in 5 UNIPROT database is in bold.

6 Table 4 SM. UNIPROT ID, Species and Taxonomy of all entries of the M17 family used for MSA.

\begin{tabular}{|c|c|c|}
\hline UNIPROT ID & Species & Taxonomy \\
\hline P28838 & Homo sapiens & $\begin{array}{c}\text { Eukaryota; Metazoa; Chordata; Craniata; } \\
\text { Vertebrata; Euteleostomi; Mammalia; Eutheria; } \\
\text { Euarchontoglires; Primates; Haplorrhini;Catarrhini; } \\
\text { Hominidae; Homo } \\
\text { Eukarvota. Metazoa. }\end{array}$ \\
\hline 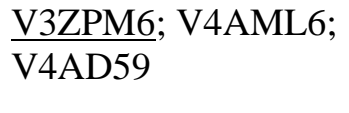 & Lottia gigantea & $\begin{array}{c}\text { Eukaryota; Metazoa; Lophotrochozoa; Mollusca; } \\
\text { Gastropoda; Patellogastropoda; Lottioidea; } \\
\text { Lottiidae; Lottia. }\end{array}$ \\
\hline$\frac{\mathrm{A} 0 \mathrm{~A} 0 \mathrm{~B} 7 \mathrm{AAC} 1}{\mathrm{~A} 0 \mathrm{~A} 0 \mathrm{~B} 7 \mathrm{~A} 4 \mathrm{~L} 9}$ & Arion vulgaris & $\begin{array}{l}\text { Eukaryota; Metazoa; Lophotrochozoa; Mollusca; } \\
\text { Gastropoda; Heterobranchia; Euthyneura; } \\
\text { Panpulmonata; Eupulmonata; Stylommatophora; } \\
\text { Sigmurethra; Arionoidea; Arionidae; Arion. }\end{array}$ \\
\hline $\begin{array}{l}\text { W4ZBD0; W4ZBJ1 } \\
\text { W4YD71; W4Y6L8 } \\
\text { W4Z491 }\end{array}$ & $\begin{array}{c}\text { Strongylocentrotus } \\
\text { purpuratus }\end{array}$ & $\begin{array}{l}\text { Eukaryota; Metazoa; Echinodermata; Eleutherozoa; } \\
\text { Echinozoa; Echinoidea; Euechinoidea; Echinacea; } \\
\text { Echinoida; Strongylocentrotidae; Strongylocentrotus. }\end{array}$ \\
\hline $\begin{array}{l}\text { A7SX56; A7SX56 } \\
\text { A7T409; A7SGM8 }\end{array}$ & $\begin{array}{l}\text { Nematostella } \\
\text { vectensis }\end{array}$ & $\begin{array}{c}\text { Eukaryota; Metazoa; Cnidaria; Anthozoa; } \\
\text { Hexacorallia; Actiniaria; Edwardsiidae; } \\
\text { Nematostella. }\end{array}$ \\
\hline T2M8Q9; T2MGD2 & Hydra vulgaris & $\begin{array}{c}\text { Eukaryota; Metazoa; Cnidaria; Hydrozoa; } \\
\text { Hydroidolina; Anthoathecata; Aplanulata; Hydridae; } \\
\text { Hydra. }\end{array}$ \\
\hline$\frac{\text { A0A1X7V5U6; }}{\text { A0A1X7UYT5 }}$ & $\begin{array}{l}\text { Amphimedon } \\
\text { queenslandica }\end{array}$ & $\begin{array}{c}\text { Eukaryota; Metazoa; Porifera; Demospongiae; } \\
\text { Heteroscleromorpha; Haplosclerida; Niphatidae; } \\
\text { Amphimedon. }\end{array}$ \\
\hline
\end{tabular}

7

8 
21 Table 5 SM. UNIPROT ID, Species and Taxonomy of all entries of the M18 family used for MSA.

\begin{tabular}{|c|c|c|}
\hline UNIPROT ID & Species & Taxonomy \\
\hline Q9ULA0 & Homo sapiens & $\begin{array}{c}\text { Eukaryota; Metazoa; Chordata; Craniata; } \\
\text { Vertebrata; Euteleostomi; Mammalia; Eutheria; } \\
\text { Euarchontoglires; Primates; Haplorrhini;Catarrhini; } \\
\text { Hominidae; Homo }\end{array}$ \\
\hline V3Z7I6 & Lottia gigantea & $\begin{array}{c}\text { Eukaryota; Metazoa; Lophotrochozoa; Mollusca; } \\
\text { Gastropoda; Patellogastropoda; Lottioidea; } \\
\text { Lottiidae; Lottia. }\end{array}$ \\
\hline$\underline{\mathrm{A} 0 \mathrm{~A} 0 \mathrm{~B} 7 \mathrm{ACW} 1}$ & Arion vulgaris & $\begin{array}{l}\text { Eukaryota; Metazoa; Lophotrochozoa; Mollusca; } \\
\text { Gastropoda; Heterobranchia; Euthyneura; } \\
\text { Panpulmonata; Eupulmonata; Stylommatophora; } \\
\text { Sigmurethra; Arionoidea; Arionidae; Arion. }\end{array}$ \\
\hline A7RHL4 & $\begin{array}{c}\text { Nematostella } \\
\text { vectensis }\end{array}$ & $\begin{array}{c}\text { Eukaryota; Metazoa; Cnidaria; Anthozoa; } \\
\text { Hexacorallia; Actiniaria; Edwardsiidae; } \\
\text { Nematostella. }\end{array}$ \\
\hline T2M3F8 & Hydra vulgaris & $\begin{array}{c}\text { Eukaryota; Metazoa; Cnidaria; Hydrozoa; } \\
\text { Hydroidolina; Anthoathecata; Aplanulata; Hydridae; } \\
\text { Hydra. }\end{array}$ \\
\hline$\frac{\text { A0A1X7UM67; }}{\text { A0A1X7T6D9 }}$ & $\begin{array}{l}\text { Amphimedon } \\
\text { queenslandica }\end{array}$ & $\begin{array}{c}\text { Eukaryota; Metazoa; Porifera; Demospongiae; } \\
\text { Heteroscleromorpha; Haplosclerida; Niphatidae; } \\
\text { Amphimedon. }\end{array}$ \\
\hline
\end{tabular}

22 


\begin{tabular}{|c|c|c|c|c|c|}
\hline Species & Optimal pH & $\begin{array}{l}\% \text { residual Activity vs } \\
1.10 \text {-phenantroline (1 }\end{array}$ & $\begin{array}{l}\% \text { residual Activity } \\
\text { vs amastatin (100 }\end{array}$ & $\begin{array}{c}\text { IC }_{50} \text { bestatin } \\
(\mu \mathrm{M})^{\mathrm{b}}\end{array}$ & $\begin{array}{c}\mathrm{K}_{\mathrm{M}} \text { vs L-LeuAMC } \\
(\mu \mathrm{M})^{\mathrm{b}}\end{array}$ \\
\hline & & $\mathrm{mM})^{\mathrm{a}}$ & $\mu \mathrm{M})^{\mathrm{a}}$ & & \\
\hline Nerita peloronta & $4.0-5.0 / 7.5$ & 6 & 59 & $1.43 \pm 0.01$ & $8.83 \pm 0.84$ \\
\hline Nerita versicolor & $4.0-5.0 / 7.5$ & 8 & 59 & $2.10 \pm 0.01$ & $7.95 \pm 0.91$ \\
\hline Lissodendoryx (Lissodendoryx) isodictyalis & $4.5 / 9.0$ & 12 & 59 & $86.0 \pm 22.8$ & $17.56 \pm 3.41$ \\
\hline Tripneustes ventricosus & $4.5 / 7.0$ & 3 & 53 & $9.37 \pm 0.01$ & $15.77 \pm 3.85$ \\
\hline Echinaster (Othilia) echinophorus & 7.0 & 0.3 & 35 & $0.27 \pm 0.02$ & $10.84 \pm 2.46$ \\
\hline Stichodactylahelianthus & $6.0-8.0$ & 6 & 70 & $3.34 \pm 0.02$ & $20.93 \pm 1.81$ \\
\hline Bunodosoma granuliferum & 8.0 & 9 & 51 & $4.33 \pm 0.01$ & $66.84 \pm 13.67$ \\
\hline Physalia physalis & $5.0 / 9.0-10.0$ & 6 & 61 & $15.2 \pm 4.25$ & $24.91 \pm 5.42$ \\
\hline rPfA-M17 & $8.5^{26}$ & 6 & 71 & $0.43 \pm 0.05$ & 43.33 \\
\hline$h L A P$ & $9.0-9.5^{1}$ & 19 & 73 & $34.4 \pm 7.67$ & ND \\
\hline$h A P N$ & $7.0-8.0$ & 1 & 57 & $19.9 \pm 5.47$ & 25.53 \\
\hline$P f A-M I$ & $7.4^{30}$ & $+^{30}$ & $+^{30}$ & $0.28^{37}$ & $60^{27}$ \\
\hline$r P f-M 18$ & $7.5^{12}$ & $8^{12}$ & $\mathrm{NI}^{12}$ & $\mathrm{NI}^{12}$ & $\mathrm{NA}^{41}$ \\
\hline
\end{tabular}

40 The substrate was L-Leu-AMC at $0.025 \mathrm{mmol} / \mathrm{L} .{ }^{a}$ : Inhibition by 1,10-phenanthroline and amastatin in percentage of residual Enzyme Activity; results for rPfAM17,

41 hLAP and hAPN are from this study or from references indicated in superscript. NI: No inhibition. ND: Not determined. ${ }^{\text {b: }}$ data are expressed as mean \pm standard

42 deviation, $\mathrm{n}=3$. The protein concentration for each crude extract was: Nerita peloronta $(0.42 \mathrm{mg} / \mathrm{mL})$, Nerita versicolor $(0.29 \mathrm{mg} / \mathrm{mL})$, Lissodendoryx (Lissodendoryx) 43 isodictyalis $(1.31 \mathrm{mg} / \mathrm{mL})$, Tripneustes ventricosus $(0.74 \mathrm{mg} / \mathrm{mL})$, Echinaster (Othilia) echinophorus $(0.07 \mathrm{mg} / \mathrm{mL})$, Stichodactyla helianthus (0.42 $\mathrm{mg} / \mathrm{mL})$, 44 Bunodosoma granuliferum $(0.09 \mathrm{mg} / \mathrm{mL})$ and Physalia physalis $(5.47 \mathrm{mg} / \mathrm{mL})$. 